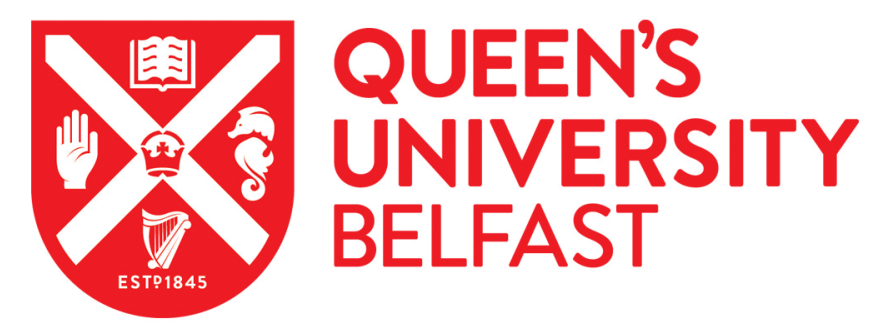

\title{
Pharmacogenetic biomarkers of response in Crohn's disease
}

\author{
Linares-Pineda, T., Canadas Garre, M. L., Sanchez-Pozo, A., \& Calleja Hernandez, M. A. (2017). \\ Pharmacogenetic biomarkers of response in Crohn's disease. The pharmacogenomics journal, 1-13. \\ https://doi.org/10.1038/tpj.2017.27
}

\section{Published in:}

The pharmacogenomics journal

\section{Document Version:}

Peer reviewed version

\section{Queen's University Belfast - Research Portal:}

Link to publication record in Queen's University Belfast Research Portal

\section{Publisher rights}

Copyright Macmillan Publishers Limited 2017. This work is made available online in accordance with the publisher's policies. Please refer to any applicable terms of use of the publisher.

\section{General rights}

Copyright for the publications made accessible via the Queen's University Belfast Research Portal is retained by the author(s) and / or other copyright owners and it is a condition of accessing these publications that users recognise and abide by the legal requirements associated with these rights.

Take down policy

The Research Portal is Queen's institutional repository that provides access to Queen's research output. Every effort has been made to ensure that content in the Research Portal does not infringe any person's rights, or applicable UK laws. If you discover content in the Research Portal that you believe breaches copyright or violates any law, please contact openaccess@qub.ac.uk. 
Title:

PHARMACOGENETIC BIOMARKERS OF RESPONSE IN CROHN'S DISEASE

\section{RUNNING TITLE:}

\section{GENETIC PREDICTORS OF RESPONSE IN CROHN'S DISEASE}

\section{AUTHORS:}

Teresa María Linares Pinedaa ${ }^{a}$ Marisa Cañadas-Garre ${ }^{a, c}$, Antonio Sánchez-Pozo ${ }^{b}$, Miguel Ángel Calleja-Hernández ${ }^{a}$.

\section{Author for correspondence}

Marisa Cañadas-Garre, Ph.D.

Centre for Public Health

School of Medicine, Dentistry and Biomedical Sciences

Queen's University Belfast

Institute of Clinical Sciences, Block B

Royal Victoria Hospital

Grosvenor Road

Belfast BT12 6BJ

Northern Ireland, UK

Telephone: +4402890976438

Fax: $\quad$ +4402890976438

E-mail: $\quad$ marisacgarre@gmail.com

\section{Affiliations}

Pharmacogenetics Unit

UGC Provincial de Farmacia de Granada

Instituto de Investigación Biosanitaria de Granada

Complejo Hospitalario Universitario de Granada

Avda. Fuerzas Armadas, 2, Granada18014

b Department of Biochemistry

Faculty of Pharmacy

University of Granada

Campus Universitario de Cartuja, s/n

18071 Granada, Spain

Telephone: $\quad+34958243838$

Fax: $\quad+34901021804$ 


\section{Centre for Public Health}

School of Medicine, Dentistry and Biomedical Sciences

Queen's University Belfast

Institute of Clinical Sciences, Block B

Royal Victoria Hospital

Grosvenor Road

Belfast BT12 6BJ

Northern Ireland, UK

Mails

Teresa María Linares-Pineda

Marisa Cañadas-Garre

Miguel Ángel Calleja-Hernández

Antonio Sánchez-Pozo teresamaria712@gmail.com

marisacgarre@gmail.com

mangel.calleja.sspa@juntadeandalucia.es

sanchezpster@gmail.com

Keywords:

Adalimumab

Infliximab

Crohn disease

Drugs therapy

Polymorphism, Single Nucleotide

WORD COUNT (excluding references and figure legends):

Abstract: $\quad 181$ words

Main Text: $\quad 4710$ words

\section{CONFLICT OF INTEREST}

The authors declare that there is not conflict of interest that could be perceived as prejudicing the impartiality of the research reported and there is not any competing financial interest in relation to the work described in this article. 


\section{PHARMACOGENETIC BIOMARKERS OF RESPONSE IN CROHN'S DISEASE}

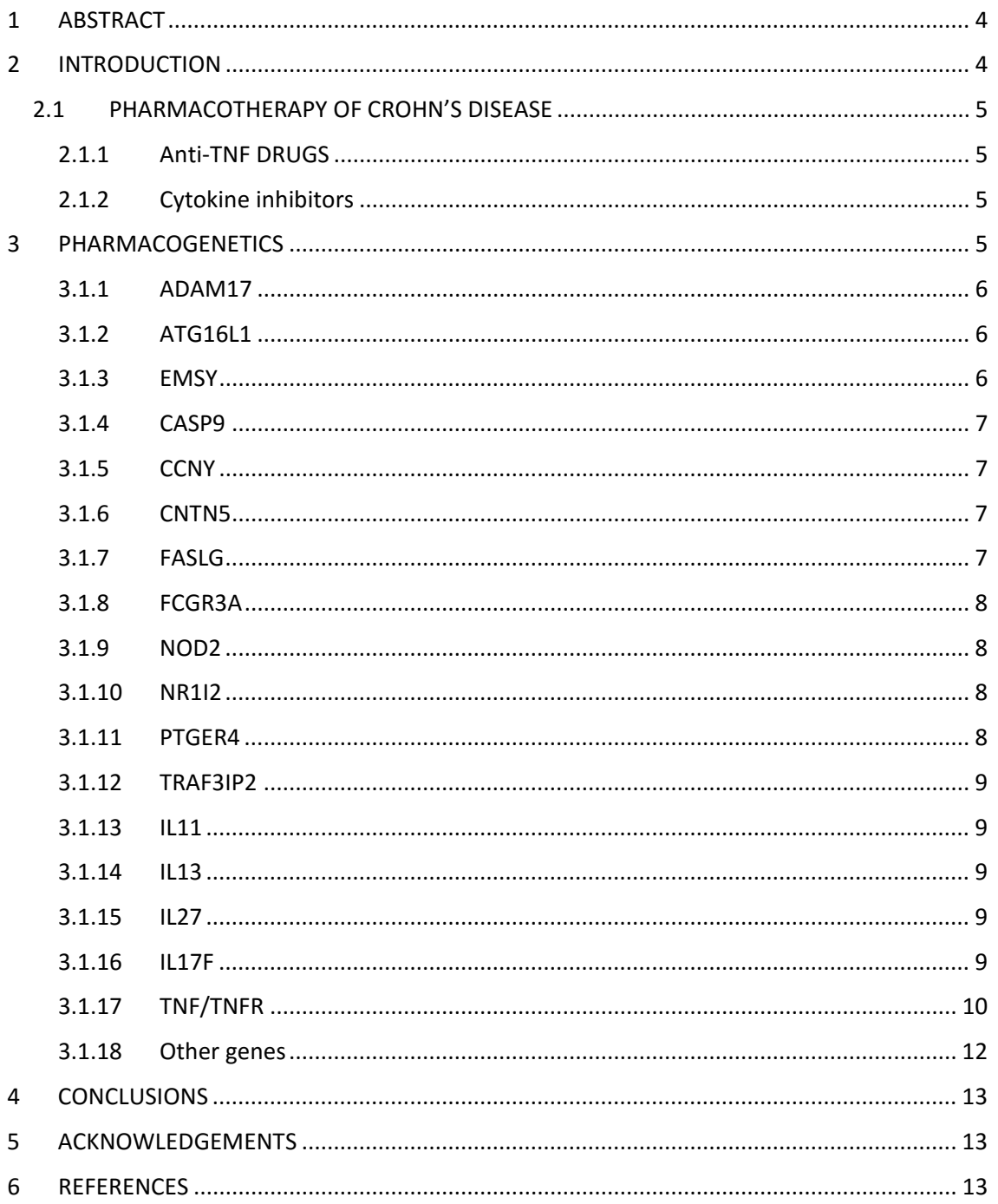




\section{ABSTRACT}

Crohn's disease (CD) is a chronic condition which affects to the immune system. It can affect to any part of the digestive tract and be associated with external manifestations. The causes of the disease remain unknown, although it seems to be the result of a combination of factors, such as genetic predisposition, environment, lifestyle and the composition of the microbiota, among others. The treatment protocol begins with a change in eating and smoking habits, and is continued with different lines of treatment, including corticosteroids, immunomodulators, and biologic therapy (infliximab and adalimumab), which have shown differences in response among patients, especially with biologic treatment. Several studies have considered the possibility that these differences in response are caused by the genetic variability of patients. Many genes have been investigated as potential predictors of response to biological drugs such as ADAM17, ATG16L1, EMSY, CASP9, CCNY, CNTN5, FASLG, FCGR, NOD2, PTGER4, IL13, IL1B, IL27, IL11, IL17F, $T N F$, and TNFR genes. In this review, we will gather the information on influence of gene polymorphisms investigated to date on response to biological drugs in CD patients.

\section{INTRODUCTION}

Crohn's disease (CD) is a chronic condition which affects to the immune system. It can affect to any part of the digestive tract and be associated with external manifestations. Fistulas and/or stenosis are commonly developed, which are explained by the transmural nature and tendency to fibrosis of the disease. It is also characterized by cycles of active disease and remission periods (1).

According to a recent study, the incidence is higher in developed industrialized countries, such those in Europe and North America, where it reaches values of 12.7 to 20.2/100,000 (2). The prevalence is also increased in these countries, reaching values of 322-319/100,000 (2).

The causes of the disease remain unknown, although it seems to be the result of a combination of factors, such as genetic predisposition (mainly abnormalities in genes of the immune system), environment and lifestyle (hygiene, diet, sleep, stress, smoking habits...), medication (particularly non-steroidal anti-inflammatory drugs), and the composition of the microbiota, among others $(3,4)$. Smoking is one of the risk factors associated with CD (OR:1.76; CI95\%:1.42.22) (5); even passive smokers have shown increased risk develop this disease (6). Individuals from large families who have been breastfed and also exposed to farm animals from an early age have shown decreased CD risk, which is directly related to the composition of their microbiota (7). Patients with greater diversity in their microbiota are less predisposed to inflammatory bowel disease (IBD) and especially to CD. Many other factors such as hygiene, infections, antibiotic use have also been associated to CD (8-11). Appendectomy is another factor that has been associated with the onset of the disease after 20 years (12). In relation to diet, several studies corroborate that a fibre-rich, fat-low diet decreases the risk of $C D$, whereas fat-rich, vitamin $D$ deficient diets are related to the appearance of IBD $(13,14)$. CD family antecedents are present in 2-14\% of CD patients; furthermore, the risk of IBD after the thirties increases in 1 out of 3 individuals when both parents are affected, showing a strong genetic influence (8). Among the genetic factors, there are DNA regions related to the immune system which have shown a high association with CD (9). A recent study in 75000 patients has identified 163 risk genes for CD (10). Some of the genes included in these regions are NOD2 (also known as CARD15), associated with a 20-40 fold increased risk in homozygous patients, and a 2-4 fold increase in heterozygotes (11,12); HLA, ATL16L1, IRGM and SLC11A1 $(9,13)$. Other genes involved with the immune response which are associated with the onset of the disease are the NF-kB gene (14), interleukin genes IL1, IL6, IL23R (15), and CARD9 (13). Some, but not all of these genes have been investigated as potential biomarkers of outcomes in biological therapy for CD. In this article, we will review the research studies conducted to date focused on the influence of gene polymorphisms on response to biological drugs in $\mathrm{CD}$ patients. 


\subsection{PHARMACOTHERAPY OF CROHN'S DISEASE}

The severity of the disease needs to be assessed to define the treatment. The Crohn's disease activity index (CDAI) quantifies the inflammatory activity and measures 8 variables, including 7 clinical and one analytical parameter (16). A greater CDAI score indicates higher severity of the disease. The level of C-reactive protein (CRP) is another parameter used to assess the degree of the disease activity, since high levels are often associated with CD.

When CDAI>220 and CRP levels $>10 \mathrm{mg} / \mathrm{l}$ are reached, it is considered as active disease. Remission is established when CDAl is less than 150, and response when CDAl decreases 100 points from baseline (17). Response to treatment is usually complemented with a questionnaire to the patient, the Inflammatory Bowel Disease Questionnaire (IBDQ), to assess their quality of life (18). The Harvey-Bradshaw Index (HBI) is a simple index of Crohn's disease activity also used to quantify the symptoms of $C D(19)$.

The $C D$ treatment guidelines start from changing eating and smoking habits, as they have proven to be a factor for the occurrence and recurrence of the disease (15). The treatment protocol is then continued with corticosteroids such as prednisone, prednisolone and budesonide, or aminosalicylic acid (17). Complementation with immunomodulators (azathioprine and mercaptopurine), which are never used as monotherapy, is used when symptoms persist. Methotrexate is recommended when there is no response to the above treatments or they are contraindicated. When the disease becomes serious, the patient is switched to biological therapy with tumour necrosis factor inhibitors (anti-TNF), mainly adalimumab (ADA) and infliximab (IFX). And finally, when the disease is recurrent despite treatments, surgery is recommended (17). More recently, studies are also being carried out with other biological drugs, like cytokine inhibitors such as natalizumab, vedolizumab (20) and ustekinumab (21) for CD treatment. Other drugs have also been tested for CD therapy, but with less success, such as tofacitinib and abatacept $(22,23)$. The pharmacogenetics of none of the latter has been studied.

\subsubsection{Anti-TNF DRUGS}

The anti-TNF drugs are recombinant human IgG1 antibody proteins, with similar functions but differently obtained. ADA is a protein obtained from recombinant DNA in mammalian cells(24), whereas IFX is a chimeric protein derived from mice(25).

\subsubsection{Cytokine inhibitors}

Several cytokine inhibitors have been tests in CD patients:

- Natalizumab: recombinant humanized anti- $\alpha 4$-integrin antibody produced on a murine cellular line by recombinant DNA technology (26).

- Vedolizumab: Humanized monoclonal antibody IgG type that binds to human $\alpha 4 \beta 7$ integrin and is produced in hamster ovary cell (27).

- Ustekinumab: monoclonal IgGk anti-interleukin 12/23 human antibody, produced in a mouse myeloma cell line using recombinant DNA technology (28).

\section{PHARMACOGENETICS}

Pharmacogenetics studies the influence of variations in the DNA sequence on drug response (29). The use of biological drugs (ADA, IFX) as one of the lines of treatment for CD has greatly improved the outcomes, but has also showed a great variability in response among patients. Several studies have considered the possibility that these differences in response are caused by genetic variability of patients (30-33). In this regard, different lines of research carried out in recent years have tried to associate variants of ADAM17, ATG16L1, EMSY, CASP9, CCNY, CNTN5, Fas Ligand, FCGR, NOD2, NR1I2, PTGER4, IL13, IL1B, IL27, IL11, IL17F, TNF, TRAF3IP2 and TNFR genes with the response to treatment with biologics in CD. Some of them, like ATG16L1, NOD2 
have also been associated with $\mathrm{CD}$ and that prompted the interest in exploring their potential role in CD outcomes to biological therapies.

\subsubsection{ADAM17}

$A D A M 17$ is a gene whose transcriptomic product leads to a protein that binds to the membrane and displays functions related to cell-cell biological processes and cell-matrix interactions. It is also involved in processes of muscle development, neurogenesis and fertilization. Furthermore, the proteins of the ADAM family are structurally related to snake venom disintegrins $(34,35)$.

Several variants in ADAM17 gene (rs2001658, rs12469362, rs883399, rs1048610, rs2276338, rs1056204, rs10929587, rs1880439, rs10495565, rs4464248, rs11684747, rs10929590) were investigated in 222 Caucasian patients treated with IFX, including luminal and fistulizing cases (33). Remission was considered if CDAl was below 150 at week 4 for patients with luminal CD. For patients with fistulizing $C D$, remission was considered if they had complete absence of fistula drainage at week 10. A decrease of 70 points in CDAl from baseline at week 4 was considered response in luminal patients, while in fistulizing patients the definition of response was a decrease of $50 \%$ of the fistula drainage at two consecutive visits at week 10. Changes in CRP levels were evaluated at weeks $0,4,8$ and 12 . No association of the different haplotypes with remission or response to IFX was shown. However, the rs2001658TT, rs12469362CC, rs883399GG, rs1048610CC, rs2276338CC, rs1056204CC, rs10929587TT, rs10495565GG, rs4464248AA, rs11684747AA haplotype was significantly less frequent in the clinical nonresponders ( $p=0.0027)$ (Table 1$)$. Interestingly, all homozygous patients for this haplotype $(n=16)$ presented clinical response according to a CDAl and also biological response according to CRP (40\%relative reduction). The haplotype composed by rs12469362C, rs1056204C, rs10495565G and rs4464248A in homozygosis was significantly associated with response to IFX (nonadjusted $\mathrm{P}<0.002)$.

\subsubsection{ATG16L1}

The ATG16L1 gene is located on chromosome 2 and encodes a protein related to autophagy processes. It has been observed that defects in this gene can cause susceptibility to inflammatory bowel disease (36).

In order to investigate the influence on response to ADA of different single gene polymorphisms (SNP) associated to CD risk, 33 SNP in 31 genes were sequenced in 102 Slovak patients with CD (37). NOD2, IL23R, SLC22A5, SLC22A4, CTLA4, PTGER4, CASP9, IL27, EMSY, CCNY, IL13, NR1/2 were among the genes studied. Response was measured using the IBDQ and CRP levels at 4, 12, 20 and 30 weeks. The T-allele of the rs 10210302 variant of the ATG16L gene showed the strongest association with response at 12 weeks (OR: 9.44, CI95\%: 2.49- 35.83, pc=0.027, $\left.p=8.11 \cdot 10^{-4}\right)$, and was maintained after 20 weeks $\left(p=4.5 \cdot 10^{-3}\right)$ (Table 1 and 2$)$. Patients carrying the T-allele also showed higher variation in CRP levels after 12 weeks $\left(p c=0.059, p=1.79 \cdot 10^{-3}\right)$ and 20 weeks $\left(p=7.6 \cdot 10^{-3}\right)$. Furthermore, patients with the TT genotype maintained the good response to $A D A$, according to IBDQ after $20\left(p=4.61 \cdot 10^{-02}\right)$ and 30 weeks of treatment $\left(\mathrm{p}=4.93 \cdot 10^{-02}\right)$ (Tabla 2).

\subsubsection{EMSY}

This gene is also known as C11orf30, is located on chromosome 11 and its $\mathrm{N}$-terminal domain is related to the BRCA2 protein, silencing the gene activation (38).

The CC genotype of the rs7927894 variant was associated with lower levels of CPR and a better IBDQ score in 102 Slovak patients with CD (37). In particular, the difference between the ADA response in CC patients was even greater at week 20, compared with those carrying the T allele $\left(\mathrm{p}=5.83 \cdot 10^{-03}, \mathrm{pc}=0.192\right)$ (Table 2$)$. 


\subsubsection{CASP9}

CASP9 gene, located on chromosome 1, encodes the caspase 9 protein, involved in the apoptosis signalling pathway. It belongs to the family of cysteine-aspartic proteases. CASP9 protein can be proteolysed and activated by the action of the apoptosome $(39,40)$.

The influence of several apoptosis-related genes (FASLG, FAS, TNFRSF10A, CASP3, CASP9, BAD, $B C L 2, B I R C 5, M M P 1, M M P 3$ ) on response to treatment was investigated in 287 CD patients (204 luminal/83 fistulizing) treated with IFX complemented with immunomodulators (azathioprine/mercaptopurine) (31). Total response was considered when CDAl reached a score of 150 or a decline of 70 points compared to initial CDAI; luminal CD response was measured after 4 weeks and fistulizing CD at week 10. The rs 4645983 variant in CASP9 was associated to response only in patients with luminal CD (Table 1). Specifically, the TT genotype was associated with a better response (OR: 1.50, CI95\%: 1.34-1.68, $\mathrm{p}=0.044$ ). The good effect of the TT genotype on response to anti-TNF drugs was also recently shown in 102 CD Slovak patients treated with ADA (Table 2) (37). In fact, all responders at week 12 presented the TT genotype. However, this effect became non-significant after Bonferroni correction.

\subsubsection{CCNY}

This gene is known as cyclin $Y$ and encodes a protein which regulates cell cycle and different transcription factors. One of their main functions is to activate the promoter of v-myc avian myelocytomatosis viral oncogene homolog $(M Y C)$ proto-oncogene, which promotes cell cycle progression and takes part in apoptosis and cellular transformation (41).

A recent study showed better response in patients carrying the CC-genotype of the rs 12777960 variant of the CCNY gene in 102 Slovak CD patients treated with ADA for 4 weeks (OR:3.26, CI95\%: $\left.1.27-8.38, \mathrm{p}=1.56 \cdot 10^{-02}, \mathrm{pc}=0.515\right)$. An improvement in CRP levels was also showed after 12 and 20 weeks $\left(p=6.78 \cdot 10^{-3}, p c=0.224\right)$ (Table 2$)$ (37).

\subsubsection{CNTN5}

The CNTN5 gene is located on chromosome 11 and encodes a cell adhesion molecule (contactin $5)$, a member of the immunoglobulin superfamily, which mediates cell surface interactions during nervous system development. Alternative names for this gene are NB-2 and HNB-2s (42).

Gene polymorphisms rs1568885, rs1813443, and rs4411591 in CNTN5 have been recently investigated in a cohort of 126 Greek CD patients treated with IFX (43). Remission was established according to HBI, CRP levels and ileocolonoscopy at weeks 0,12 and 20. The T-allele of rs 1568885 variant was associated to lower response rate (TT: OR moderate/good: 8.14 , CI95\%: 1.35 -

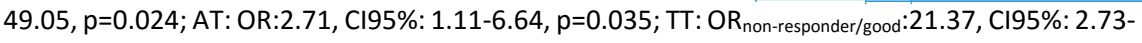
167.2, $p=0.007 /$ AT: OR: 4.75, Cl95\%: 1.26-17.9, $p=0.032$ ) (Table 1). The CC-genotype of the rs1813443 polymorphism was associated to poor response (ORmoderate/good: 6.13, Cl95\%: 1.74-

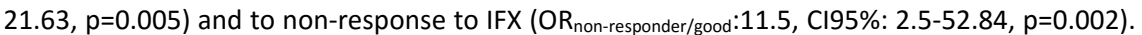
The rs4411591 variant did not showed association to drug response.

\subsubsection{FASLG}

FASLG, located on chromosome 1, encodes the Fas ligand, a transmembrane protein which binds the FAS receptor to induce apoptosis. Its function is closely related to the regulation of the immune system $(44,45)$.

Twenty-one gene polymorphisms in several genes involved in the apoptotic process (FASLG, FAS, TNFRSF10A, CASP3, CASP9, BAD, BCLXI, API4, MMP1, MMP3) were investigated in a cohort of 287 CD patients treated with IFX (204 refractory luminal and 83 fistulizing) (31). Total response was considered for patients with CDAl score of 150 or a decrease of 70 units from the baseline value, and was evaluated at 4 weeks for luminal patients and at 10 weeks for fistulising cases. Remission in fistulising patients was defined as disappearance of open fistulas, and moderate 
response when open fistules drainage had reduced less than $50 \%$. The C-alelle of the rs763110 variant of the FASLG gene was associated to better response to IFX in both luminal and fistulising patients (luminal: OR:0.11, CI95\%:0.08-0.56, $p=0.002$; fistulising: OR:1.66, CI95\%: 1.21-2.29, $\mathrm{p}=0.02$ ) (Table 1). However, the $\mathrm{C}$-allele has also been associated to a higher risk of hypersensitivity reactions to IFX in 126 CD patients (OR: 4.0, CI95\%: 1.1-22.4, p=0.041) (46). This study also investigated the effect of rs75622480 and rs5030772 polymorphisms in FASLG, failing to find any association to response to IFX.

\subsubsection{FCGR3A}

FCGR3A gene, also known as FCYRIIIA, encodes a protein related to the immune system, specifically with the antibody dependent response (47). It is located on chromosome 1 and has different variants. Specifically, the T>G substitution at rs396991 (F158V) gene polymorphism corresponds to the change of the aminoacid phenylalanine (F) by valine (V) at position 175 of the protein. $F$ presents low affinity for IgG, whereas $V$ shows high affinity (48).

The high affinity variant (VV) of the F158V polymorphism was associated with a better response to IFX in a cohort of 344 CD patients (Table 1) (49). Patients with baseline CRP values within the two highest quartiles ( $n=156)$ carrying the VV genotype showed a trend toward a greater relative change in CRP at week 6 ( $p=0.085$, one-tailed $p=0.043)$. This effect of the VV genotype on CRP improvement was further confirmed in a cohort of 102 Japanese CD patients (Table 1) (50). Response was evaluated according to CDAI and CPR levels at 8 and 30 weeks. The VV genotype was associated to CPR improvement at week $8(p=0.044)$, but the effect was not significant after 30 weeks. This study also investigated the potential influence of other polymorphisms in FCGR3A gene (FCGR3A-159, FCGR3A-160), but no associations were found (50).

Other studies with smaller samples (106 and 189 patients) have failed to find an effect of F158V variant on response to IFX in CD patients $(51,52)$.

\subsubsection{NOD2}

The NOD2 gene encodes the caspase recruitment domain-containing protein 15 (CARD15) or inflammatory bowel disease protein 1 (IBD1). Its main function is to activate NFKB protein in bacterial infections, by recognizing the muramyl dipeptide moiety $(53,54)$. It has also been related to CD susceptibility(55).

The association of NOD2 variants (rs2066844 or R702W, rs2066845 or G908R and rs2066847 L1007Profs) with relapse after IFX treatment was investigated in 14 CD patients, with no effect observed (56). In consonance with this, these variants did not influence response to ADA either in 102 Slovak CD patients treated (according to IBDQ and CRP levels measured at 4, 12, 20 and 30 weeks) (37) or 16 CD patients (evaluated by CDAl after 52 weeks) (57). Remission after IFX treatment was not associated either to NOD2 polymorphisms (G881R, G908R, R675W, R702W, 980fs, 3020insC) in 534 patients with active CD (Table 1 and 2) (58).

\subsubsection{NR1/2}

The NR1/2 gene is located in chromosome 3 and encodes a protein which belongs to the superfamily of nuclear receptors, whose main function is to bind response elements, as receptor $X$ retinone (RXR), to regulate CYP3A4 transcription $(59,60)$. The GG genotype in rs3814057 polymorphism of NR12 gene showed a trend to good long-term response to ADA ( $p=9.64 \cdot 10^{-3}$, pcorr $=0.318$ ) in 102 Slovak CD patients, but the statistical significance was lost after multiple comparison correction (Table 2) (37).

\subsubsection{PTGER4}

PTGER4 gene, located in chromosome 5, encodes a prostaglandin receptor which belongs to the G-protein coupled receptor family and is one of four receptors identified for prostaglandin E2. It acts by activating signalling factors of T cells (61). 
The GG genotype of the PTGER4 rs10512734 variant has showed a trend to short-term response in 102 Slovak CD patients (week 12: $p=4.62 \cdot 10^{-3}$, pcorr=0.152) (Table 2) (37).

\subsubsection{TRAF3IP2}

Located in the chromosome 6 , the protein encoded by this gene is involved in the process of regulating the immune system in response to pathogens, inflammatory and stress signals. Specifically, it regulates cytokine response to Rel/NF-kappaB transcription factors $(62,63)$.

The association of several variants of this gene (rs10872070, rs6941014, rs1883136, rs1040383, rs9374263, rs2075966) with response to IFX was studied in 113 Japanese CD patients. Only the rs183136 polymorphism was associated with response to IFX after 1 year of treatment, showing a lower frequency of the AA genotype (recessive model) in responders (OR ${ }_{C / A A}: 0.213, C I 95 \%$ : 0.053-0.860, $p=0.041)($ Table 1)(64).

\subsubsection{IL11}

The protein encoding this gene is interleukin 11, whose main function is to stimulate the development of $\mathrm{T}$ cell dependent immunoglobulin produced by B lymphocytes. It belongs to the gp130 family of cytokines, with the role of assembling the receptors subunits contained in the IL6ST transmembrane signalling molecule (gp130) (65).

The influence of rs116760 and rs1042506 polymorphisms in IL11 gene on response to IFX were investigated in 350 patients (Table 3) (66). Response criteria were established as $\mathrm{HBl}<4$ for luminal $C D$ and $100 \%$ fistulae healing for fistulising CD patients; partial responders were defined as $\mathrm{HBl}<3$ and $>50 \%$ reduction in fistulae, respectively. The rs1126760_C y rs1042506_T haplotype was associated with better response to IFX (OR: $1.72,95 \% \mathrm{Cl}: 0.91-\overline{3} .21, \mathrm{p}=0.068)(66)$.

\subsubsection{IL13}

IL13 gene is located in chromosome 5, and encodes a cytokine mainly involved in immune processes. Its transcription is activated by Th2 cells, and leads to the activation of IgG4 and IgE synthesis in B cells (67).

The AA genotype of the rs1295686 variant of IL13 gene was associated to long-term response (over week 20) to ADA (Table 2), according to IBDQ values in 102 Slovak CD patients $\left(p=6.07 \cdot 10^{-}\right.$ $\left.{ }^{3}, \mathrm{pc}=0.2\right)$ (37). Patients with AA genotype improved IBDQ at week 30 compared to patients with the $G$ allele $\left(p=1.84 \cdot 10^{-2}, p c=0.607\right)$.

\subsubsection{IL27}

The IL27 gene is located on chromosome 16 and encodes one of the subunits of a heterodimeric cytokine which participates in protection against virus, by promoting proliferation of naive CD4+ T cells (68).

The rs 8049439 variant of IL27 gene was found to be associated with response to ADA after 4 weeks, according to IBDQ and CRP in $102 \mathrm{CD}$ patients. The T-allele was more frequent among responders, compared with the CC genotype (OR: 9.67, CI95\%: 1.65, 56.22, $p=9.71-10^{-3}$, $\mathrm{pc}=0.320)$; increased CRP was higher in patients with TT genotype compared to CC patients $\left(p=1.61 \cdot 10^{-2}, p c=0.531\right)$. Regarding IBDQ, the T-allele also presented a trend to better response $\left(p=2.96 \cdot 10^{-02}, p c=0.977\right)$ (Table 2) (37).

\subsubsection{IL17F}

IL17F gene is located on chromosome 6 , and its protein product is involved in the defence against pathogens, since it is expressed in the mucosa and epithelial barrier. It is also expressed in CD4+ T lymphocytes and monocytes activated, and works as a recruiter of leukocytes (neutrophils), promoting granulopoiesis and inducing inflammation by activating cytokines like IL6, IL8, IL2 and GSF2/GM_CSF $(69,70)$. 
The association of different variants of this gene (rs763780, rs766748, rs12201582, rs9382084, rs722323, rs1266828, rs2294934) with response was studied in 113 Japanese CD patients treated with IFX (Table 3). Response was defined as decrease in CDAl less than 150, while no changes in CDAl or exacerbation of disease activity was categorized as non-response. Among the different polymorphisms studied, only rs766748 was associated with response after a year of treatment. In particular, the dominant model for the A-allele was less frequent among responders (OR:0.203, $p=0.019)(64)$. This study also included different polymorphisms of genes related to IL17 as were IL17A (rs4711998, rs8193036, rs3819024, rs2275913, rs3819025), IL17RA (rs2270241, rs2241042, rs5748863, rs5748864, rs2241049, rs2229151, rs2895332), IL17R (rs7627880, rs279545). None of these polymorphisms showed association with response to IFX.

\subsubsection{TNF/TNFR}

The main function of the tumour necrosis factor (TFN) gene is to promote immune response and processes involved in inflammation, differentiation, proliferation, apoptosis and coagulation. It is located in chromosome 6 . The superfamily of TNF receptors (TNFRSF10A, TNFR1, TNFR2 and TNFRSF1B), important for the proper functioning of the immune system, are also related with this gene (71). Mutations in these genes are strongly related with autoimmune diseases $(32,72,73)$.

The extensive study of TNF gene has yielded many polymorphisms potentially associated to response to biological therapy in CD patients, among them rs1799724, rs1799964, rs1800629, and rs361520 (Table 4).

\subsubsection{TNF - 238}

The variant in position -238 of the promoter region of the TNF gene (rs361525) did not show influence on response to IFX in 106 Greek CD patients after 20 weeks (51). Song et al. recently investigated the influence of several TNF gene polymorphisms on response to biological therapy, especially anti-TNF, in patients with different autoimmune diseases (psoriasis, ankylosing spondylitis and CD) in a meta-analysis which included 16 studies (including 7 in CD patients) and 983 ( 452 with CD) patients (72). The $\mathrm{G}$ variant was associated to good response to treatment in the overall population (OR:2.208, Cl95\%:1.197-4.074, $\mathrm{p}=0.011$ ), particularly for Caucasian patients (OR:2.196, Cl95\%:1.161-4.154). However, the stratification by disease did not show association of this polymorphism with response.

\subsubsection{TNF -308}

A study with 23 CD patients treated with IFX showed a high number of A carriers of the TNF-308 (rs1800629) variant in the nonresponding group (74). The influence of this SNP on response to anti-TNF was also investigated in the recent meta-analysis by Song et al., showing the rs $1800629 \mathrm{G}$ variant was associated to response in the overall population with different autoimmune diseases (OR:1.388, Cl95\%: 1.388-2.150, $\mathrm{p}=0.000012$ ) and in Caucasians (OR:2.005, CI95\%: 1.417-2.38, $p=0.000086$ ), but not Asians. This effect was also evident in the $496 \mathrm{CD}$ patients (OR:1.508, CI95\%: 0.973-2.338, $\mathrm{p}=0.066$ ) from 8 studies and in spondylitis patients (72).

\subsubsection{TNF -857}

The -857 variant ( $r$ 1799724), located in the promoter region of TNF gene, was also investigated in the recent meta-analysis by Song et al. (72). The C-allele was associated with good response to anti-TNF in the overall population (OR:1.889, Cl95\%: 1.245-2.866, $\mathrm{p}=0.003$ ), particularly in Caucasian patients (OR:1.779, Cl95\%: 1.319-3.790, $\mathrm{p}=0.03$ ). The stratification by disease failed to confirm this association individually. 


\subsubsection{TNFRSF1A}

The TNFRSF1A, also known as TNFR1, located in chromosome 12, encodes the $1 \mathrm{~A}$ member from the TNF superfamily of receptors. It is activated after NF-K $\beta$ binding, promoting apoptosis $(75,76)$.

A recent study has investigated the role of two polymorphisms in TNFRSF1A (rs767455 and rs4149570) on response to IFX in 80 CD patients, according to HBI index (32). The rs 4149570 polymorphism did not show any influence on response to IFX, but patients carrying the G-alelle of rs767455 variant experienced reduced effectiveness of IFX, compared to AA patients (OR:0.37, Cl95\%: 0.11-0.82), and this association remained after adjust by clinical and sociodemographic variables, such as age, sex, disease location and life-style (OR:0.26, CI95\%: 0.08-0.9). In consonance with this, a recent meta-analysis in autoimmune diseases (including 2 studies compiling $377 \mathrm{CD}$ patients) has found a trend of the A-allele to better response to antiTNF therapy (Table 4)(73).

The G-allele of the A36G (Pro12Pro) variant has been associated with lower response to IFX in $344 \mathrm{CD}$ patients, defined as CDAI decrease to 70 points or normalized CDAl in 150 points (OR: $0.47, \mathrm{Cl} 95 \%: 0.234-0.946, \mathrm{p}=0.0343)$, although biological response (CRP) was not associated (Table 4) (77).

Other polymorphisms in TNFRSF1A ( $r$ 4149584, rs4149570, and rs4149569) have showed no effect on response or adverse reactions in 126 CD patients treated with IFX (Table 4) (46).

\subsubsection{TNFRSF1B}

The TNFRSF1B, also known as TNFR2, is located in chromosome 1, encodes the $1 \mathrm{~b}$ member from the TNF superfamily of receptors, whose function is to recruit anti-apoptotic proteins C-IAP1 and C-IAP2 (75).

The rs1061624A/rs3397T haplotype has been associated with worse response to IFX, according to HBI index, in 297 Spanish CD patients (OR:1.78, C95\%: 1.09-2.9, $\mathrm{p}=0.015)(78)$ and 80 Japanese CD patients $(p=0.01)(32)$. In the Spanish study, the rs1061624A variant was also more frequent in non-responders (OR:1.63, Cl95\%:1.05-2.51, $\mathrm{p}=0.02$ ), and the CC-genotype of the rs3397 variant was associated with better response rates (OR:3.19, Cl95\%:0.95-16.78, $p=0.05$ ) (Table 4) (78).

The effect of three variants in TNFRSF1B gene ( $r$ s976881, rs1061622, rs652625) on response to IFX after 12 weeks, measured according to HBI index, was evaluated in $126 \mathrm{CD}$ patients (46). The T-allele of the rs652625 variant was related to a decreased risk of adverse reactions to IFX (OR:0.2, p=0.043), whereas the GG genotype of rs976881 variant and the G-allele of rs1061622 polymorphism were associated to better response (OR:3.3, CI95\%:1.2-9.1, $p=0.014$; OR:5.5, CI95\%:1.5-25.5, $\mathrm{p}=0.007$, respectively) (46). Although other studies have not found the rs1061622 variant associated with response (32), the good effect of rs1061622G allele of TNFRSF1B gene has been recently confirmed in a meta-analysis including 1062 patients (377 with $C D$ ) from 8 studies in different autoimmune diseases (psoriasis, rheumatoid arthritis and $\mathrm{CD}$ ), showing the T-allele associated to no response in the overall population (OR:0.72, C195\%: $0.57-0.93, p=0.08)(73)$. The stratification by disease only confirmed the effect on rheumatoid arthritis and psoriasis, but not in CD, probably due only 2 studies were included. The rs1061624 polymorphism was associated with worse/absence of response in the heterozygote (AG vs GG: OR: $2.54,95 \% \mathrm{Cl}: 1.30-4.96, \mathrm{p}=0.007$ ) and dominant models (AA/AG vs GG: OR: $2.07,95 \% \mathrm{Cl}: 1.10-$ $3.93, p=0.025)$ in the meta-analysis (73). The $\mathrm{rs} 3397$ was also associated with non-response in the heterozygote model ( $\left.\mathrm{OR}_{\mathrm{CT} \text { vs } \mathrm{T}}: 1.17,95 \% \mathrm{Cl}: 0.68-2.02, \mathrm{p}=0.026\right)$. These associations were lost after stratification by disease. The rs1061622 (T587G) polymorphism in the TNFRSF1B gene did not show any influence on response to IFX in 344 CD patients, according to CDAl improvement and CPR levels (Table 4) (77). 


\subsubsection{TNFAIP6}

TheTNFAIP6 gene encodes a protein involved in the stability of the extracellular matrix and cell migration. Proteins which develop this type of function are characterized by secreting properties and present a hyaluron binding domain (79-81).

The association of different variants of this gene ( $r s 11677200, r s 2342910, r s 3755480$, rs10432475) with response to IFX was studied in 350 CD patients (66). The rs11677200_C/ rs2342910_A/ rs3755480A/ rs10432475A haplotype showed a trend to better response to IFX (OR: 0.71; 95\%Cl: 0.46-1.09; $\mathrm{p}=0.10$ ) (Table 4).

\subsubsection{Other genes}

During the last decade, the influence of other genes on response to biological therapy in patients with $C D$ has also been investigated, although with poor results. Some of these genes are $C D 14$, $T L R A, M D R 1, A B C G 2, L T A, C R P$, mainly related to the immune response or the onset of the disease. Genes related with calcium canals like S100A9, S100A12, S100A8, and surviving promoters have also been investigated. No influence of any of these genes was found with response to treatment in $\mathrm{CD}$.

In some studies, the small sample size may have provoked the lack of association. CD14 (rs2569190) and TLRA (rs4986790) polymorphisms showed no effect on response to IFX or ADA in 24 Spanish CD patients after 52 weeks (57). ABCB1 (rs2032582 and rs1045642) and ABCG2 (rs2231137 and rs1131142) polymorphisms were investigated in 47 CD patients treated with IFX, but no significant associations with response were observed. The IBD5 locus includes the IGR variants IGR2060a_1G>C (rs20522057) and IGR3081a_1T>G (82), whose potential association with remission (CDAI $<150$ ) vs relapses after IFX discontinuation was investigated in $14 \mathrm{CD}$ patients (56). Relapse after treatment was defined as loss of IFX-induced remission (CDAI $>220$ ), or evidence of active CD in patients who discontinued IFX. No association was found, probably due to the small size of the sample. The predictive value of the IL1B rs 1143634 variant in IFX response was investigated in $29 \mathrm{CD}$ and 18 ulcerative colitis patients. CRP and ESR levels were estimated after 3, 6 and 12 months. Response was considered when the improvement in CDAl was over 70 points, compared to baseline (Table 3) (83). In this case, despite of the small size sample, the $\mathrm{C}$-allele was associated to poorer clinical remission after 14 weeks of treatment $(p=0.027)$ and also showed a trend to worse response $(p=0.051)$.

Several LTA gene polymorphisms (rs909253, rs2857713, rs5875327, rs1041981, rs746868, 3093543) were investigated in a group of 264 patients with CD treated with IFX for 12 weeks (84). No association with response to IFX was found, not even after considering the potential influence of combined haplotypes.

Like in the above examples, the association of different polymorphisms in CRP gene (-717G/A, $+1444 \mathrm{C} / \mathrm{T}, 4 \mathrm{~A} / \mathrm{G}$ ) with the response to treatment IFX (CDAI, CRP) could not be demonstrated in $189 \mathrm{CD}$ patients(52).

Several variants in genes related to calcium channels, like S100A9 (rs11205276, rs30141866), S100A12(rs724781), S100A8 ( $r$ 3006488) were investigated as possible predictors of response to IFX in 350 CD patients (66). The S100A9 (rs11205276_G, rs3014866_C) and S100A8 (rs724781_C, rs3006488_A) haplotypes were associated with non-response (OR: 1.54, 95\%Cl: $0.97,2.43 ; p=0.05)$. The same study also explored the influence of polymorphisms in the GOS2 gene (rs4844486, rs2342910, rs3755480, rs10432475), which showed a trend to worse response in patients carrying the rs4844486_A/rs14733683_T haplotype (OR: $0.15 ; 95 \% \mathrm{Cl}$ : $0.45,15.23$; $\mathrm{p}=0.15)(66)$.

Polymorphisms in surviving promoters $(-625 \mathrm{G} / \mathrm{C},-241 \mathrm{~T} / \mathrm{C},-31 \mathrm{C} / \mathrm{T})$ have been investigated in a cohort of 97 Greek CD patients, but no influence on IFX was observed (85). 
Other genes involved in apoptosis ( $B A D, B C L X I, A P I 4, M M P 1, M M P 3)$ were investigated in 287 $C D$ patients treated with IFX, but none of them showed association with response (86).

\section{CONCLUSIONS}

In the past decades, a great effort has been done to find pharmacogenetic biomarkers capable to predict the response to biologic therapy in CD patients. Many genes have been explored, and despite some polymorphisms emerged with a great potential, particularly in members of the TNF family, the overall results are poor and no good predictive biomarkers for IFX or ADA response have been established. Although some of these biomarkers have showed influence on response to biologic therapy in other inflammatory diseases, their effect in CD patients is not clearly demonstrated. The cause of this lack of association may be the small size of the studies undertaken, even the meta-analyses, and the few studies available for each gene. Therefore, a more thorough investigation of the pharmacogenetics of $C D$ therapy is still needed, employing more comprehensive sets of genes or even large-scale unbiased studies, in large cohorts of patients, as a better approach to identify better biomarkers for CD pharmacotherapy.

\section{ACKNOWLEDGEMENTS}

The results of this investigation are part of the doctoral thesis presented by Teresa María Linares Pineda at the University of Granada.

\section{REFERENCES}

1. Kalla R, Ventham NT, Satsangi J, Arnott IDR. Crohn's disease. BMJ [Internet]. 2014 Jan [cited 2015 Aug 11];349:g6670. Available from: http://www.ncbi.nlm.nih.gov/pubmed/25409896

2. Molodecky NA, Soon IS, Rabi DM, Ghali WA, Ferris M, Chernoff G, et al. Increasing incidence and prevalence of the inflammatory bowel diseases with time, based on systematic review. Gastroenterology [Internet]. 2012 Jan [cited 2016 Jun 10];142(1):4654.e42; quiz e30. Available from: http://www.ncbi.nlm.nih.gov/pubmed/22001864

3. Ananthakrishnan AN. Epidemiology and risk factors for IBD. Nat Rev Gastroenterol Hepatol [Internet]. 2015 Mar 3 [cited 2015 Mar 4];12(4):205-17. Available from: http://www.ncbi.nlm.nih.gov/pubmed/25732745

4. Ananthakrishnan AN, Higuchi LM, Huang ES, Khalili H, Richter JM, Fuchs CS, et al. Aspirin, Nonsteroidal Anti-inflammatory Drug Use, and Risk for Crohn Disease and Ulcerative Colitis. Ann Intern Med [Internet]. American College of Physicians; 2012 Mar 6 [cited 2016 Jun 10];156(5):350. Available http://annals.org/article.aspx?doi=10.7326/0003-4819-156-5-201203060-00007

5. Mahid SS, Minor KS, Soto RE, Hornung CA, Galandiuk S. Smoking and Inflammatory Bowel Disease: A Meta-analysis. Mayo Clin Proc [Internet]. 2006 Nov [cited 2016 Nov 5];81(11):1462-71. Available from: http://linkinghub.elsevier.com/retrieve/pii/S0025619611612536

6. Mahid SS, Minor KS, Stromberg AJ, Galandiuk S. Active and Passive Smoking in Childhood Is Related to the Development of Inflammatory Bowel Disease. Inflamm Bowel Dis [Internet]. 2007 Apr [cited 2016 Nov 5];13(4):431-8. Available from: http://content.wkhealth.com/linkback/openurl?sid=WKPTLP:landingpage\&an=0005472 5-200704000-00010

7. Timm S, Svanes C, Janson C, Sigsgaard T, Johannessen A, Gislason T, et al. Place of upbringing in early childhood as related to inflammatory bowel diseases in adulthood: a population-based cohort study in Northern Europe. Eur J Epidemiol [Internet]. Springer; 2014 Jun [cited 2016 Nov 5];29(6):429-37. Available from: 
http://www.ncbi.nlm.nih.gov/pubmed/24916994

8. Halme L, Paavola-Sakki P, Turunen U, Lappalainen M, Farkkila M, Kontula K. Family and twin studies in inflammatory bowel disease. World J Gastroenterol [Internet]. Baishideng Publishing Group Inc; 2006 Jun 21 [cited 2016 Nov 5];12(23):3668-72. Available from: http://www.ncbi.nlm.nih.gov/pubmed/16773682

9. Muro M, López-Hernández R, Mrowiec A. Immunogenetic biomarkers in inflammatory bowel diseases: role of the IBD3 region. World J Gastroenterol [Internet]. 2014 Nov 7 [cited 2016 Jun 10];20(41):15037-48. Available from: http://www.ncbi.nlm.nih.gov/pubmed/25386052

10. Liu JZ, van Sommeren S, Huang H, Ng SC, Alberts R, Takahashi A, et al. Association analyses identify 38 susceptibility loci for inflammatory bowel disease and highlight shared genetic risk across populations. Nat Genet [Internet]. Europe PMC Funders; 2015 Sep [cited 2016 Dec 11];47(9):979-86. Available from: http://www.ncbi.nlm.nih.gov/pubmed/26192919

11. Hugot JP, Chamaillard M, Zouali H, Lesage S, Cézard JP, Belaiche J, et al. Association of NOD2 leucine-rich repeat variants with susceptibility to Crohn's disease. Nature [Internet]. 2001 May 31 [cited 2016 Nov 5];411(6837):599-603. Available from: http://www.ncbi.nlm.nih.gov/pubmed/11385576

12. Ogura $\mathrm{Y}$, Bonen DK, Inohara N, Nicolae DL, Chen FF, Ramos R, et al. A frameshift mutation in NOD2 associated with susceptibility to Crohn's disease. Nature [Internet]. 2001 May 31 [cited 2016 Nov 5];411(6837):603-6. Available from: http://www.ncbi.nlm.nih.gov/pubmed/11385577

13. de Lange KM, Barrett JC. Understanding inflammatory bowel disease via immunogenetics. J Autoimmun [Internet]. 2015 Aug 6 [cited 2015 Aug 17]; Available from: http://www.ncbi.nlm.nih.gov/pubmed/26257098

14. Philpott DJ, Sorbara MT, Robertson SJ, Croitoru K, Girardin SE. NOD proteins: regulators of inflammation in health and disease. Nat Rev Immunol [Internet]. 2014 Jan [cited 2014 Oct 31];14(1):9-23. Available from: http://www.ncbi.nlm.nih.gov/pubmed/24336102

15. Enfermedad de Crohn [Internet]. [cited 2015 Sep 20]. Available from: http://www.elsevierinstituciones.com/ficheros/booktemplate/9788475927220/files/Ca pitulo25.pdf

16. van der Heijde DM, van 't Hof M, van Riel PL, van de Putte LB. Development of a disease activity score based on judgment in clinical practice by rheumatologists. J Rheumatol [Internet]. 1993 Mar [cited 2016 Jun 6];20(3):579-81. Available from: http://www.ncbi.nlm.nih.gov/pubmed/8478878

17. Dignass A, Van Assche G, Lindsay JO, Lémann M, Söderholm J, Colombel JF, et al. The second European evidence-based Consensus on the diagnosis and management of Crohn's disease: Current management. J Crohns Colitis [Internet]. 2010 Feb [cited 2015 Mar 23];4(1):28-62. Available from: http://www.ncbi.nlm.nih.gov/pubmed/21122489

18. IBD Surveys/Questionnaires for Clinical Practice. [cited 2016 Jul 19]; Available from: http://www.sciencedirect.com/science/article/pii/S0022399905004915\#

19. Harvey RF, Bradshaw JM. A SIMPLE INDEX OF CROHN'S-DISEASE ACTIVITY. Lancet [Internet]. Elsevier; 1980 Mar [cited 2016 Jul 26];315(8167):514. Available from: http://linkinghub.elsevier.com/retrieve/pii/S0140673680927671

20. Mozaffari S, Nikfar S, Abdolghaffari AH, Abdollahi M. New biologic therapeutics for ulcerative colitis and Crohn's disease. Expert Opin Biol Ther [Internet]. 2014 May 6 [cited 
2016 Nov 4];14(5):583-600. Available from: http://www.tandfonline.com/doi/full/10.1517/14712598.2014.885945

21. Sandborn WJ, Gasink C, Gao L-L, Blank MA, Johanns J, Guzzo C, et al. Ustekinumab Induction and Maintenance Therapy in Refractory Crohn's Disease. N Engl J Med [Internet]. 2012 Oct 18 [cited 2016 Nov 4];367(16):1519-28. Available from: http://www.nejm.org/doi/abs/10.1056/NEJMoa1203572

22. Vuitton L, Koch S, Peyrin-Biroulet L. Janus kinase inhibition with tofacitinib: changing the face of inflammatory bowel disease treatment. Curr Drug Targets [Internet]. 2013 Nov [cited 2016 Nov 4];14(12):1385-91. Available from: http://www.ncbi.nlm.nih.gov/pubmed/23627915

23. Mayer L, Kaser A, Blumberg RS. Dead on Arrival: Understanding the Failure of CTLA4Immunoglobulin Therapy in Inflammatory Bowel Disease. Gastroenterology [Internet]. 2012 Jul [cited 2016 Nov 4];143(1):13-7. Available from: http://linkinghub.elsevier.com/retrieve/pii/S0016508512007433

24. European Medicines Agency - Find medicine - Humira [Internet]. Available from http://www.ema.europa.eu/ema/index.jsp?curl=pages/medicines/human/medicines/0 00481/human_med_000822.jsp\&mid=WC0b01ac058001d124

25. European Medicines Agency - Find medicine - Remicade [Internet]. Available from: http://www.ema.europa.eu/ema/index.jsp?curl=pages/medicines/human/medicines/0 00240/human_med_001023.jsp\&mid=WC0b01ac058001d124

26. European Medicines Agency - Find medicine - Tysabri [Internet]. Available from http://www.ema.europa.eu/ema/index.jsp?curl=pages/medicines/human/medicines/0 00603/human_med_001119.jsp\&mid=WC0b01ac058001d124

27. European Medicines Agency - Find medicine - Entyvio [Internet]. Available from: http://www.ema.europa.eu/ema/index.jsp?curl=pages/medicines/human/medicines/0 02782/human_med_001751.jsp\&mid=WC0b01ac058001d124

28. European Medicines Agency - Find medicine - Stelara [Internet]. Available from http://www.ema.europa.eu/ema/index.jsp?curl=pages/medicines/human/medicines/0 00958/human_med_001065.jsp\&mid=WC0b01ac058001d124

29. Definitions for genomic biomarkers, pharmacogenomics, pharmacogenetics, genomic data and sample coding categories. [Internet]. [cited 2016 May 9]. Available from: http://www.ema.europa.eu/docs/en_GB/document_library/Scientific_guideline/2009/ 09/WC500002880.pdf

30. Murdaca G, Spanò F, Contatore M, Guastalla A, Magnani O, Puppo F. Pharmacogenetics of etanercept: role of TNF- $\alpha$ gene polymorphisms in improving its efficacy. Expert Opin Drug Metab Toxicol [Internet]. 2014 Dec [cited 2016 Jun 10];10(12):1703-10. Available from: http://www.ncbi.nlm.nih.gov/pubmed/25300969

31. Hlavaty $T$, Pierik M, Henckaerts L, Ferrante $M$, Joossens S, Van Schuerbeek N, et al. Polymorphisms in apoptosis genes predict response to infliximab therapy in luminal and fistulizing Crohn's disease. Aliment Pharmacol Ther. 2005;22(7):613-26.

32. Matsukura H, Ikeda S, Yoshimura N, Takazoe M, Muramatsu M. Genetic polymorphisms of tumour necrosis factor receptor superfamily $1 \mathrm{~A}$ and $1 \mathrm{~B}$ affect responses to infliximab in Japanese patients with Crohn's disease. Aliment Pharmacol Ther. 2008;27(9):765-70.

33. Dideberg $\mathrm{V}$, Théâtre $\mathrm{E}$, Farnir $\mathrm{F}$, Vermeire $\mathrm{S}$, Rutgeerts $\mathrm{P}$, De Vos $\mathrm{M}$, et al. The TNF/ADAM 17 system: implication of an ADAM 17 haplotype in the clinical response to infliximab in Crohn's disease. Pharmacogenet Genomics. 2006;16(10):727-34. 
34. Black RA, Rauch CT, Kozlosky CJ, Peschon JJ, Slack JL, Wolfson MF, et al. A metalloproteinase disintegrin that releases tumour-necrosis factor-alpha from cells. Nature [Internet]. 1997 Feb 20 [cited 2016 Jun 30];385(6618):729-33. Available from: http://www.ncbi.nlm.nih.gov/pubmed/9034190

35. Patel IR, Attur MG, Patel RN, Stuchin SA, Abagyan RA, Abramson SB, et al. TNF-alpha convertase enzyme from human arthritis-affected cartilage: isolation of cDNA by differential display, expression of the active enzyme, and regulation of TNF-alpha. J Immunol [Internet]. 1998 May 1 [cited 2016 Jun 30];160(9):4570-9. Available from: http://www.ncbi.nlm.nih.gov/pubmed/9574564

36. Scolaro BL, dos Santos E, Ferreira LE, França PHC de, Kleinubing Jr H, Kotze PG, et al. T300A genetic polymorphism: a susceptibility factor for Crohn's disease? Arq Gastroenterol [Internet]. [cited 2016 Jun 30];51(2):97-101. Available from: http://www.ncbi.nlm.nih.gov/pubmed/25003259

37. Koder S, Repnik K, Ferkolj I, Pernat C, Skok P, Weersma RK, et al. Genetic polymorphism in ATG16L1 gene influences the response to adalimumab in Crohn's disease patients. Pharmacogenomics [Internet]. 2015 [cited 2016 Jun 10];16(3):191-204. Available from: http://www.ncbi.nlm.nih.gov/pubmed/25712183

38. Hughes-Davies L, Huntsman D, Ruas M, Fuks F, Bye J, Chin S-F, et al. EMSY links the BRCA2 pathway to sporadic breast and ovarian cancer. Cell [Internet]. Elsevier; 2003 Nov 26 [cited 2016 Jun 30];115(5):523-35. Available from: http://www.ncbi.nlm.nih.gov/pubmed/14651845

39. Duan H, Orth K, Chinnaiyan AM, Poirier GG, Froelich CJ, He WW, et al. ICE-LAP6, a novel member of the ICE/Ced-3 gene family, is activated by the cytotoxic $T$ cell protease granzyme B. J Biol Chem [Internet]. 1996 Jul 12 [cited 2016 Jun 30];271(28):16720-4. Available from: http://www.ncbi.nlm.nih.gov/pubmed/8663294

40. Li P, Nijhawan D, Budihardjo I, Srinivasula SM, Ahmad M, Alnemri ES, et al. Cytochrome C and dATP-Dependent Formation of Apaf-1/Caspase-9 Complex Initiates an Apoptotic Protease Cascade. Cell [Internet]. Elsevier; 1997 Nov [cited 2016 Jun 30];91(4):479-89. Available from: http://linkinghub.elsevier.com/retrieve/pii/S0092867400804341

41. Li X, Wang X, Liu G, Li R, Yu L. Identification and characterization of cyclin X which activates transcriptional activities of c-Myc. Mol Biol Rep [Internet]. 2009 Jan [cited 2016 Jun 30];36(1):97-103. Available from: http://www.ncbi.nlm.nih.gov/pubmed/18060517

42. Kamei Y, Takeda Y, Teramoto K, Tsutsumi O, Taketani Y, Watanabe K. Human NB-2 of the Contactin Subgroup Molecules: Chromosomal Localization of the Gene (CNTN5) and Distinct Expression Pattern from Other Subgroup Members. Genomics. 2000;69(1):1139.

43. Thomas D, Gazouli M, Karantanos T, Rigoglou S, Karamanolis G, Bramis K, et al. Association of rs1568885, rs1813443 and rs4411591 polymorphisms with anti-TNF medication response in Greek patients with Crohn's disease. World J Gastroenterol. 2014;20(13):3609-14.

44. Takahashi T, Tanaka M, Inazawa J, Abe T, Suda T, Nagata S. Human Fas ligand: gene structure, chromosomal location and species specificity. Int Immunol [Internet]. 1994 Oct [cited 2016 Jun 30];6(10):1567-74. Available from: http://www.ncbi.nlm.nih.gov/pubmed/7826947

45. Stuart PM, Griffith TS, Usui N, Pepose J, Yu X, Ferguson TA. CD95 ligand (FasL)-induced apoptosis is necessary for corneal allograft survival. J Clin Invest [Internet]. 1997 Feb 1 [cited 2016 Jun 30];99(3):396-402. Available from: 
http://www.ncbi.nlm.nih.gov/pubmed/9022072

46. Steenholdt C, Enevold C, Ainsworth M a., Brynskov J, Thomsen OO, Bendtzen K. Genetic polymorphisms of tumour necrosis factor receptor superfamily $1 \mathrm{~b}$ and fas ligand are associated with clinical efficacy and/or acute severe infusion reactions to infliximab in Crohn's disease. Aliment Pharmacol Ther. 2012;36(7):650-9.

47. Qiu WQ, de Bruin D, Brownstein BH, Pearse R, Ravetch J V. Organization of the human and mouse low-affinity $\mathrm{Fc}$ gamma $\mathrm{R}$ genes: duplication and recombination. Science [Internet]. 1990 May 11 [cited 2016 May 27];248(4956):732-5. Available from: http://www.ncbi.nlm.nih.gov/pubmed/2139735

48. Koene HR, Kleijer M, Algra J, Roos D, von dem Borne AE, de Haas M. Fc gammaRIIla$158 \mathrm{~V} / \mathrm{F}$ polymorphism influences the binding of IgG by natural killer cell Fc gammaRIlla, independently of the Fc gammaRIIIa-48L/R/H phenotype. Blood [Internet]. 1997 Aug 1 [cited 2016 Apr 14];90(3):1109-14. Available from: http://www.ncbi.nlm.nih.gov/pubmed/9242542

49. Louis EJ, Watier HE, Schreiber S, Hampe J, Taillard F, Olson A, et al. Polymorphism in IgG Fc receptor gene FCGR3A and response to infliximab in Crohn's disease: a subanalysis of the ACCENT I study. Pharmacogenet Genomics. 2006;16(12):911-4.

50. Moroi R, Endo $K$, Kinouchi $Y$, Shiga $H$, Kakuta $Y$, Kuroha $M$, et al. FCGR3A-158 polymorphism influences the biological response to infliximab in Crohn's disease through affecting the ADCC activity. Immunogenetics. 2013;65(4):265-71.

51. Papamichael K, Gazouli M, Karakoidas C, Panayotou I. Association of TNF and FcyRIIIA gene polymorphisms with differential response to infliximab in a Greek cohort of Crohn 's disease patients. 2011;35-40.

52. Willot $S$, Vermeire $S$, Ohresser M, Rutgeerts P, Paintaud G, Belaiche J, et al. No association between $\mathrm{C}$-reactive protein gene polymorphisms and decrease of C-reactive protein serum concentration after infliximab treatment in Crohn's disease. Pharmacogenet Genomics. 2006;16(1):37-42.

53. Gilberts EC, Greenstein AJ, Katsel P, Harpaz N, Greenstein RJ. Molecular evidence for two forms of Crohn disease. Proc Natl Acad Sci U S A [Internet]. 1994 Dec 20 [cited 2016 Jun 30];91(26):12721-4. Available from: http://www.ncbi.nlm.nih.gov/pubmed/7809109

54. Hugot JP, Laurent-Puig P, Gower-Rousseau C, Olson JM, Lee JC, Beaugerie L, et al. Mapping of a susceptibility locus for Crohn's disease on chromosome 16. Nature [Internet]. 1996 Feb 29 [cited 2016 Jun 30];379(6568):821-3. Available from: http://www.ncbi.nlm.nih.gov/pubmed/8587604

55. Germain A, Guéant R-M, Chamaillard M, Allen PB, Bresler L, Guéant J-L, et al. NOD2 gene variant is a risk factor for postoperative complications in patients with Crohn's disease: A genetic association study. Surgery [Internet]. 2016 Jul [cited 2016 Sep 3];160(1):74-80. Available from: http://www.ncbi.nlm.nih.gov/pubmed/26946932

56. Lu C, Waugh A, Bailey RJ, Cherry R, Dieleman L a., Gramlich L, et al. Crohn's disease genotypes of patients in remission vs relapses after infliximab discontinuation. World J Gastroenterol. 2012;18(36):5058-64.

57. Barreiro-de Acosta M, Ouburg S, Morré S a., Crusius JB a, Lorenzo a., Potel J, et al. NOD2, CD14 and TLR4 mutations do not influence response to adalimumab in patients with Crohn's disease: A preliminary report. Rev Esp Enfermedades Dig. 2010;102(10):591-5.

58. Mascheretti S, Hampe J, Croucher PJP, Nikolaus S, Andus T, Schubert S, et al. Response to infliximab treatment in Crohn's disease is not associated with mutations in the CARD15 
(NOD2) gene: an analysis in 534 patients from two multicenter, prospective GCP-level trials. Pharmacogenetics. 2002;12(7):509-15.

59. Lehmann JM, McKee DD, Watson MA, Willson TM, Moore JT, Kliewer SA. The human orphan nuclear receptor PXR is activated by compounds that regulate CYP3A4 gene expression and cause drug interactions. J Clin Invest [Internet]. 1998 Sep 1 [cited 2016 Aug 11];102(5):1016-23. Available from: http://www.ncbi.nlm.nih.gov/pubmed/9727070

60. Bertilsson G, Heidrich J, Svensson K, Asman M, Jendeberg L, Sydow-Bäckman M, et al. Identification of a human nuclear receptor defines a new signaling pathway for CYP3A induction. Proc Natl Acad Sci U S A [Internet]. 1998 Oct 13 [cited 2016 Aug 11];95(21):12208-13. Available from: http://www.ncbi.nlm.nih.gov/pubmed/9770465

61. Duncan AM, Anderson LL, Funk CD, Abramovitz M, Adam M. Chromosomal localization of the human prostanoid receptor gene family. Genomics [Internet]. 1995 Feb 10 [cited 2016 Jun 30];25(3):740-2. Available from: http://www.ncbi.nlm.nih.gov/pubmed/7759114

62. Li X, Commane M, Nie H, Hua X, Chatterjee-Kishore M, Wald D, et al. Act1, an NF-kappa B-activating protein. Proc Natl Acad Sci U S A [Internet]. 2000 Sep 12 [cited 2016 Sep 20];97(19):10489-93. Available from: http://www.ncbi.nlm.nih.gov/pubmed/10962024

63. Leonardi A, Chariot A, Claudio E, Cunningham K, Siebenlist U. CIKS, a connection to Ikappa B kinase and stress-activated protein kinase. Proc Natl Acad Sci U S A [Internet]. 2000 Sep 12 [cited 2016 Sep 20];97(19):10494-9. Available from: http://www.ncbi.nlm.nih.gov/pubmed/10962033

64. Urabe S, Isomoto H, Ishida T, Maeda K, Inamine T, Kondo S, et al. Genetic Polymorphisms of IL-17F and TRAF3IP2 Could Be Predictive Factors of the Long-Term Effect of Infliximab against Crohn's Disease. Biomed Res Int [Internet]. Hindawi Publishing Corporation; 2015 [cited 2016 Sep 20];2015:416838. Available from: http://www.ncbi.nlm.nih.gov/pubmed/26558270

65. McKinley D, Wu Q, Yang-Feng T, Yang YC. Genomic sequence and chromosomal location of human interleukin-11 gene (IL11). Genomics [Internet]. 1992 Jul [cited 2016 Sep 26];13(3):814-9. Available from: http://www.ncbi.nlm.nih.gov/pubmed/1386338

66. Medrano LM, Taxonera C, González-Artacho C, Pascual V, Gómez-García M, Barreiro-de Acosta M, et al. Response to Infliximab in Crohn's Disease: Genetic Analysis Supporting Expression Profile. Mediators Inflamm [Internet]. Hindawi Publishing Corporation; 2015 [cited $2016 \quad$ Sep 20];2015:318207. Available from: http://www.ncbi.nlm.nih.gov/pubmed/26339133

67. Punnonen J, Aversa G, Cocks BG, McKenzie AN, Menon S, Zurawski G, et al. Interleukin 13 induces interleukin 4-independent IgG4 and IgE synthesis and CD23 expression by human B cells. Proc Natl Acad Sci U S A [Internet]. 1993 Apr 15 [cited 2016 Jun 30];90(8):3730-4. Available from: http://www.ncbi.nlm.nih.gov/pubmed/8097323

68. Pflanz S, Timans JC, Cheung J, Rosales R, Kanzler H, Gilbert J, et al. IL-27, a heterodimeric cytokine composed of EBI3 and p28 protein, induces proliferation of naive CD4+ T cells. Immunity [Internet]. Elsevier; 2002 Jun [cited 2016 Jun 30];16(6):779-90. Available from: http://www.ncbi.nlm.nih.gov/pubmed/12121660

69. Starnes T, Robertson MJ, Sledge G, Kelich S, Nakshatri H, Broxmeyer HE, et al. Cutting edge: IL-17F, a novel cytokine selectively expressed in activated T cells and monocytes, regulates angiogenesis and endothelial cell cytokine production. J Immunol [Internet]. 2001 Oct 15 [cited 2016 May 27];167(8):4137-40. Available from: 
http://www.ncbi.nlm.nih.gov/pubmed/11591732

70. Kawaguchi M, Onuchic LF, Li XD, Essayan DM, Schroeder J, Xiao HQ, et al. Identification of a novel cytokine, ML-1, and its expression in subjects with asthma. J Immunol [Internet]. 2001 Oct 15 [cited 2016 May 27];167(8):4430-5. Available from: http://www.ncbi.nlm.nih.gov/pubmed/11591768

71. Old L. Tumor necrosis factor (TNF). Science [Internet]. 1985 Dec 8 [cited 2016 May 31];230(4726):630-2. Available from: http://www.ncbi.nlm.nih.gov/pubmed/2413547

72. Song GG, Seo YH, Kim J-H, Choi SJ, Ji JD, Lee YH. Association between TNF- $\alpha$ (-308 A/G, $238 \mathrm{~A} / \mathrm{G},-857 \mathrm{C} / \mathrm{T}$ ) polymorphisms and responsiveness to TNF- $\alpha$ blockers in spondyloarthropathy, psoriasis and Crohn's disease: a meta-analysis. Pharmacogenomics [Internet]. 2015 Jan [cited 2016 Apr 12];16(12):1427-37. Available from: http://www.ncbi.nlm.nih.gov/pubmed/26244882

73. Chen $\mathrm{W}, \mathrm{Xu} \mathrm{H}$, Wang $\mathrm{X}, \mathrm{Gu} J$, Xiong $\mathrm{H}$, Shi $\mathrm{Y}$. The tumor necrosis factor receptor superfamily member $1 B$ polymorphisms predict response to anti-TNF therapy in patients with autoimmune disease: A meta-analysis. Int Immunopharmacol [Internet]. 2015 Sep [cited 2016 Apr 12];28(1):146-53. Available from: http://www.ncbi.nlm.nih.gov/pubmed/26071216

74. Balog A, Klausz G, Gál J, Molnár T, Nagy F, Ocsovszky I, et al. Investigation of the prognostic value of TNF-alpha gene polymorphism among patients treated with infliximab, and the effects of infliximab therapy on TNF-alpha production and apoptosis. Pathobiology. 2004;71(5):274-80.

75. Schall TJ, Lewis M, Koller KJ, Lee A, Rice GC, Wong GH, et al. Molecular cloning and expression of a receptor for human tumor necrosis factor. Cell [Internet]. 1990 May 20 [cited 2016 May 31];61(2):361-70. Available from: http://www.ncbi.nlm.nih.gov/pubmed/2158863

76. Baker E, Chen LZ, Smith CA, Callen DF, Goodwin R, Sutherland GR. Chromosomal location of the human tumor necrosis factor receptor genes. Cytogenet Cell Genet [Internet]. 1991 Jan [cited 2016 May 31];57(2-3):117-8. Available from: http://www.ncbi.nlm.nih.gov/pubmed/1655358

77. Pierik $M$, Vermeire $S$, Steen $K$ V, Joossens $S$, Claessens $G$, Vlietinck $R$, et al. Tumour necrosis factor-alpha receptor 1 and 2 polymorphisms in inflammatory bowel disease and their association with response to infliximab. Aliment Pharmacol Ther. 2004;20(3):303-10.

78. Medrano LM, Taxonera C, Márquez a., Barreiro-de Acosta M, Gómez-García M, González-Artacho C, et al. Role of TNFRSF1B polymorphisms in the response of Crohn's disease patients to infliximab. Hum Immunol [Internet]. American Society for Histocompatibility and Immunogenetics; 2014;75(1):71-5. Available from: http://dx.doi.org/10.1016/j.humimm.2013.09.017

79. Lee TH, Wisniewski HG, Vilcek J. A novel secretory tumor necrosis factor-inducible protein (TSG-6) is a member of the family of hyaluronate binding proteins, closely related to the adhesion receptor CD44. J Cell Biol [Internet]. 1992 Jan [cited 2016 Sep 26];116(2):545-57. Available from: http://www.ncbi.nlm.nih.gov/pubmed/1730767

80. Wisniewski HG, Hua JC, Poppers DM, Naime D, Vilcek J, Cronstein BN. TNF/IL-1-inducible protein TSG-6 potentiates plasmin inhibition by inter-alpha-inhibitor and exerts a strong anti-inflammatory effect in vivo. J Immunol [Internet]. 1996 Feb 15 [cited 2016 Sep 26];156(4):1609-15. Available from: http://www.ncbi.nlm.nih.gov/pubmed/8568267 
81. Lesley J, Gál I, Mahoney DJ, Cordell MR, Rugg MS, Hyman R, et al. TSG-6 modulates the interaction between hyaluronan and cell surface CD44. J Biol Chem [Internet]. 2004 Jun 11 [cited 2016 Sep 26];279(24):25745-54. Available from: http://www.ncbi.nlm.nih.gov/pubmed/15060082

82. Rioux JD, Silverberg MS, Daly MJ, Steinhart AH, McLeod RS, Griffiths AM, et al. Genomewide Search in Canadian Families with Inflammatory Bowel Disease Reveals Two Novel Susceptibility Loci. Am J Hum Genet [Internet]. Elsevier; 2000 Jun [cited 2016 Jun 30];66(6):1863-70. Available http://linkinghub.elsevier.com/retrieve/pii/S0002929707635381

83. Lacruz-Guzmán D, Torres-Moreno D, Pedrero F, Romero-Cara P, García-Tercero I, TrujilloSantos J, et al. Influence of polymorphisms and TNF and IL1 $\beta$ serum concentration on the infliximab response in Crohn's disease and ulcerative colitis. Eur J Clin Pharmacol. 2013;69(3):431-8.

84. Dideberg V, Louis E, Farnir F, Bertoli S, Vermeire S, Rutgeerts $P$, et al. Lymphotoxin alpha gene in Crohn's disease patients: absence of implication in the response to infliximab in a large cohort study. Pharmacogenet Genomics. 2006;16(5):369-73.

85. Rapti E, Gazouli M, Legaki E, Karamanolis G, Thomas D, Marinos E, et al. Association of survivin promoter polymorphisms with inflammatory bowel disease and response to antitumor necrosis factor therapy. Genet Test Mol Biomarkers [Internet]. 2015 Jun [cited 2016 Sep 26];19(6):339-43. Available from: http://www.ncbi.nlm.nih.gov/pubmed/25918954

86. Hlavaty $T$, Pierik M, Henckaerts L, Ferrante $M$, Joossens S, Van Schuerbeek N, et al. Polymorphisms in apoptosis genes predict response to infliximab therapy in luminal and fistulizing Crohn's disease. Aliment Pharmacol Ther. 2005;22(7):613-26. 